\title{
Large-periodicity Two-Dimensional Crystals by
}

\section{Cocrystallization}

Katherine E. Plass, Keary M. Engle, Katie A. Cychosz, and Adam J. Matzger*

Department of Chemistry and the Macromolecular Science and Engineering Program, University of Michigan, 930 N. University, Ann Arbor, MI 48109-1055

matzger@umich.edu

\section{Supporting Information}

(1) Synthetic procedures

(2) Experimental details

(3) List of ratios at which competitive adsorption experiments were performed with the resulting surface phase

(4) Additional STM images of 18-ortho/18-meta cocrystal

(5) STM image and packing model of 20-meta

(6) Additional STM image of 18-ortho/20-meta cocrystal

(7) Model of the 18-ortho/20-meta cocrystal showing close contacts

(8) Hypothetical model of 18-ortho/18-meta cocrystal

(9) Packing coefficient and density calculations 
(1) Synthetic procedures

All solvents were purchased from Fisher Scientific. All reagents were used as received and were purchased from Acros Organics except 1-octadecanol (Sigma Chemical Co.). Column chromatography was carried out on silica gel (0.040-0.063 mm particle size, EM Sciences).

Preparation of dioctadecyl phthalate (18-ortho): To a solution of 1-octadecanol (0.8555 g, 3.16 mmol) dissolved in degassed anhydrous $\mathrm{CH}_{2} \mathrm{Cl}_{2}(20 \mathrm{~mL})$, triethylamine $(0.22 \mathrm{~mL})$, and 4dimethylaminopyridine $(13.9 \mathrm{mg}, 0.113 \mathrm{mmol})$ was added phthaloyl dichloride $(0.110 \mathrm{~mL}, 0.763$ mmol). The solution was heated to reflux under a nitrogen atmosphere for 3 days. The reaction mixture was diluted with $\mathrm{CH}_{2} \mathrm{Cl}_{2}(40 \mathrm{~mL})$ and washed with $1 \mathrm{~N} \mathrm{HCl}(50 \mathrm{~mL})$ and brine $(50 \mathrm{~mL})$, then dried over sodium sulfate. Pure product was obtained through repeated recrystallization from methyl ethyl ketone, leading to the low yield. Yield: $109.2 \mathrm{mg}(21.5 \%) . \mathrm{mp} 55.49{ }^{\circ} \mathrm{C}$ (the peak of the melting endotherm measured by differential scanning calorimetry at $\left.10{ }^{\circ} \mathrm{C} / \mathrm{min}\right)$. IR: 2956 (m), 2918 (vs), 2850 (s), 1741 (s), 1728 (s), 1714 (s), 1473 (m), 1466 (vw), 1296 (s), 1250 (m), 1140 (m), $1124(\mathrm{~m}), 1116$ (m), 1072 (m), $740(\mathrm{~m}) \mathrm{cm}^{-1} .{ }^{1} \mathrm{H}$ NMR $\left(400 \mathrm{MHz}, \mathrm{CDCl}_{3}, \delta\right): 0.88(\mathrm{t}, J=6.4 \mathrm{~Hz}, 6 \mathrm{H}), 1.22-1.43(\mathrm{~m}, 60 \mathrm{H}), 1.72$ (quint, $J=6.8 \mathrm{~Hz}, 4 \mathrm{H}), 4.29(\mathrm{t}, J=6.8 \mathrm{~Hz}, 4 \mathrm{H}), 7.53\left(\mathrm{XX}^{\prime}\right.$ in an AA'XX' spin system, $\left.2 \mathrm{H}\right), 7.71$ (AA' in an $\mathrm{AA}^{\prime} \mathrm{XX}$ ' spin system, $2 \mathrm{H}$ ). ${ }^{13} \mathrm{C} \mathrm{NMR}\left(400 \mathrm{MHz}, \mathrm{CDCl}_{3}, \delta\right): 14.12,22.69,25.97,28.54,29.31$, 29.36, 29.55, 29.61, 29.66, 29.71 (broad), 31.92, 65.88, 128.83, 130.89, 167.70. Anal. Calcd for $\mathrm{C}_{42} \mathrm{H}_{74} \mathrm{O}_{4}$ : C 78.75, H 11.72; Found: C 78.66, H 11.98. MS (CI, $\left.\mathrm{CH}_{4}\right): m / z 671.8\left[\mathrm{MH}^{+}\right]$.

Dieicosyl isophthalate (20-meta) and dioctadecyl isophthalate (18-meta) were synthesized as previously reported in Plass, K. E.; Kim, K.; Matzger, A. J. J. Am. Chem. Soc. 2004, 126, 9042-9053. 
Scanning tunneling microscopy: A Nanoscope E STM (Digital Instruments) was used for all imaging. Highly oriented pyrolytic graphite (HOPG) (SPI-1 grade, Structure Probe Inc.) was used as a substrate for monolayer formation. A $1 \mu \mathrm{L}$ drop of solution (either pure or a binary mixture) in 1phenyloctane, prepared as described in Tables S1 and S2, was placed on freshly cleaved HOPG to obtain a self-assembled monolayer. The tips were made from $\mathrm{Pt} / \mathrm{Ir}$ wire $(20 \% \mathrm{Ir}, 0.010$ inch diameter, California Fine Wire) by mechanical cutting and shaped in situ by applying short voltage pulses. The quality of the tips was verified by scanning the HOPG surface under the monolayer at reduced bias voltage. All images are unfiltered. STM imaging was performed under ambient conditions and typical STM settings include $300 \mathrm{pA}$ of current and 600-1000 mV of bias voltage (sample positive).

\section{Computational modeling:}

The packing structures apparent from the metrics and symmetry of the STM images were modeled using Cerius $^{2}$ version 4.2 (Accelrys Inc.). Energy minimization was performed using a COMPASS forcefield. The periodic three-dimensional models used in lattice energy calculations were minimized with a large $c$-axis, keeping out-of-plane parameters fixed. The computed unit cell parameters and densities were obtained from these calculations. Non-periodic assemblies from these models were overlaid on a fixed graphite slab for cluster simulations. The perturbation of the periodic structure upon simulation of adsorption to the graphite slab was minimal in all cases. 
(3) List of ratios at which competitive adsorption experiments were performed with the resulting surface phase

Table S1. Ratios of 18-ortho:18-meta in phenyloctane solution with total concentrations of $20.0 \mathrm{mg} / \mathrm{mL}$ examined by STM with the resulting two-dimensional crystalline phase:

\begin{tabular}{|c|c|}
\hline $\begin{array}{c}\text { ratio } 18- \\
\text { ortho: } 18-\text { meta }\end{array}$ & phase observed on surface \\
\hline $0: 1$ & 18-meta \\
\hline $1: 1$ & 18-meta \\
\hline $19: 1$ & 18-meta \\
\hline $24: 1$ & 18-meta \\
\hline $40: 1$ & $\begin{array}{l}\text { 18-meta (meta disappears) and } \\
\text { 18-ortho/20-meta cocrystal }\end{array}$ \\
\hline $49: 1$ & $\begin{array}{l}\text { 18-meta (meta disappears) and } \\
\text { 18-ortho/18-meta cocrystal }\end{array}$ \\
\hline $50: 1$ & 18-ortho/18-meta cocrystal \\
\hline $60: 1$ & 18-ortho \\
\hline 79.5:1 & 18-ortho \\
\hline $1: 0$ & 18-ortho \\
\hline
\end{tabular}

Table S2. Ratios of 18-ortho:20-meta in phenyloctane solution with total concentrations of $20.0 \mathrm{mg} / \mathrm{mL}$ examined by STM with the resulting two-dimensional crystalline phase:

\begin{tabular}{cc}
\hline $\begin{array}{c}\text { ratio 18- } \\
\text { ortho:20-meta }\end{array}$ & phase observed on surface \\
\hline $40: 1$ & $20-$ meta \\
$60: 1$ & $20-$ meta \\
$100: 1$ & 18-ortho/20-meta cocrystal \\
$120: 1$ & 18-ortho/20-meta cocrystal \\
$480: 1$ & $18-$ ortho \\
\hline
\end{tabular}


(4) Additional STM image of the 18-ortho/18-meta cocrystal

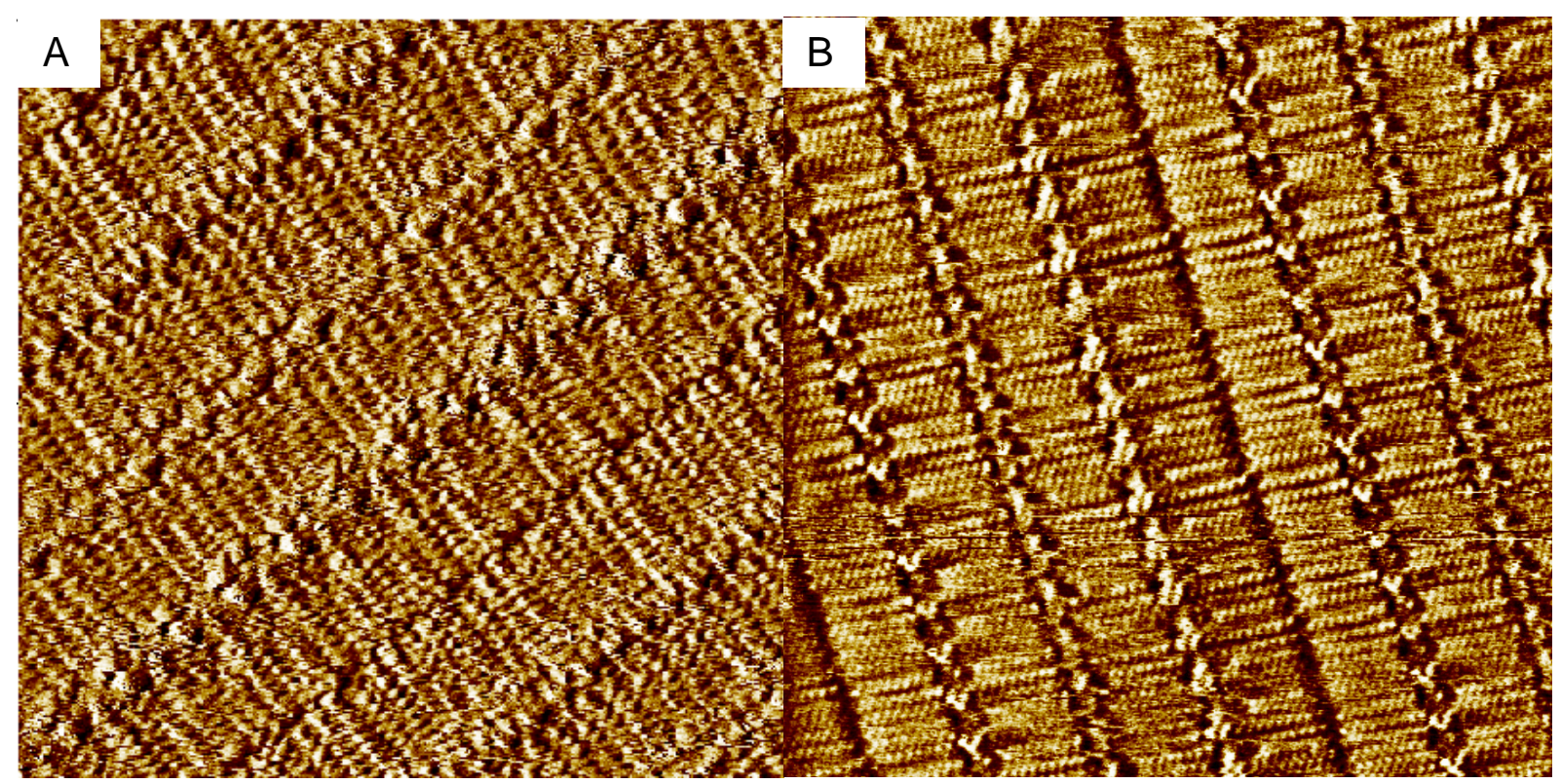

Figure S1. STM images of cocrystal packing at the phenyloctane/graphite interface from (A) 40:1 solution of 18-ortho and 20-meta $(15 \mathrm{~nm} \times 15 \mathrm{~nm}, 10.2 \mathrm{~Hz}, 700.0 \mathrm{mV}, 300 \mathrm{pA})$ and (B) 49:1 solution of 18-ortho and 20-meta $(20 \mathrm{~nm} \times 20 \mathrm{~nm}, 12.2 \mathrm{~Hz}, 1000.0 \mathrm{mV}, 300 \mathrm{pA})$. The phase is the same in both images. 
(5) STM image and packing model of 20-meta

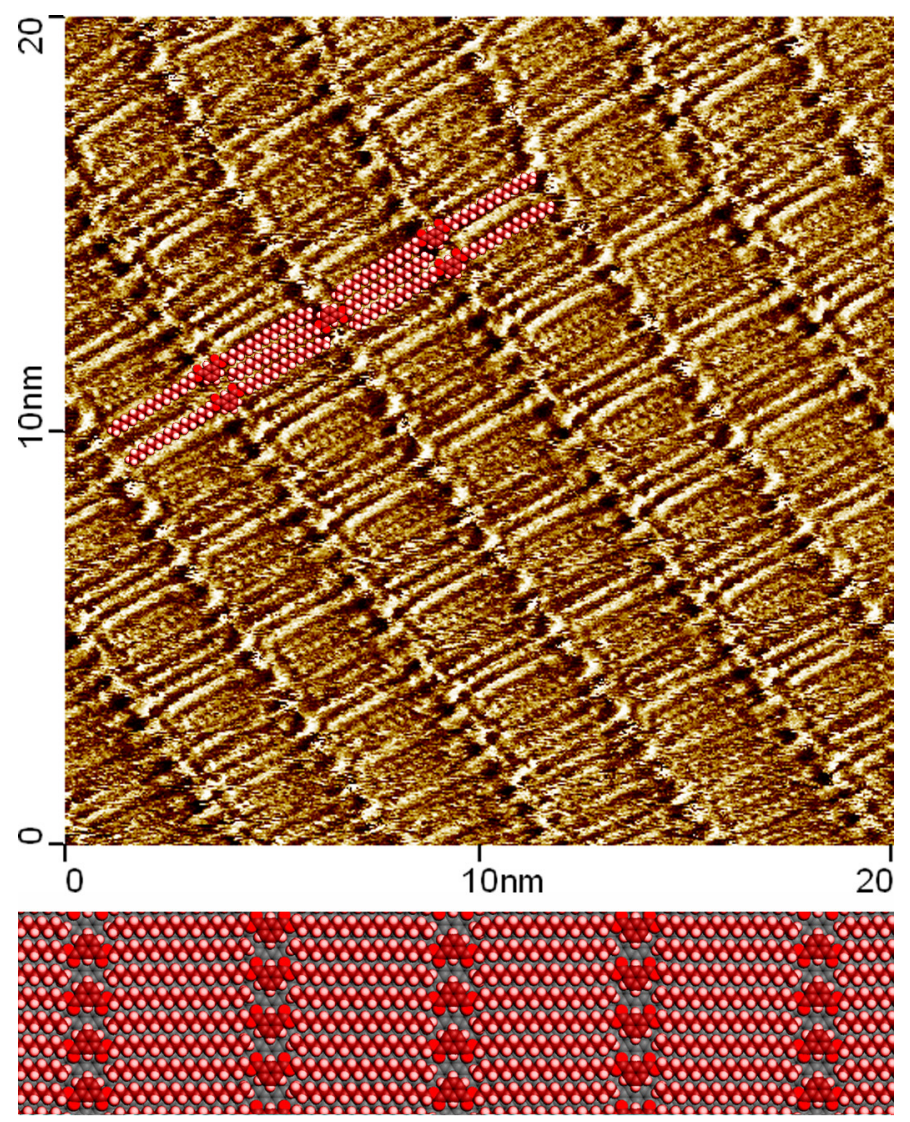

Figure S2. The two-dimensional crystal packing at the phenyloctane/graphite interface from a single component solution of 20-meta. (a) STM image (20 nm x $20 \mathrm{~nm}, 15.2 \mathrm{~Hz}$ scan rate, $800.0 \mathrm{mV}, 300 \mathrm{pA})$ with overlaid molecular model. (b) Calculated packing model of 20-meta minimized on a nonperiodic graphite slab with unit cell depicted. 
(6) Additional STM image of 18-ortho/20-meta cocrystal

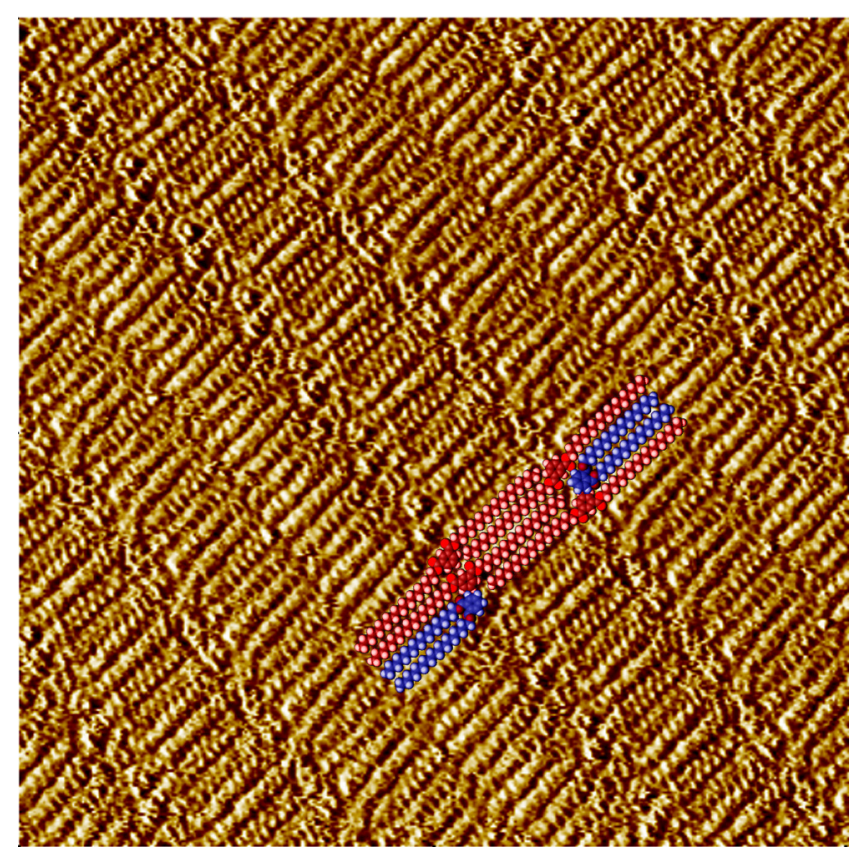

Figure S3. STM images of the cocrystal packing at the phenyloctane/graphite interface from a binary solution of 120:1 18-ortho (blue):20-meta (red) $(20 \mathrm{~nm}$ x $20 \mathrm{~nm}, 10.2 \mathrm{~Hz}, 648.5 \mathrm{mV}, 300$ pA) with overlaid molecular model. 
(7) Model of the 18-ortho/20-meta showing close contacts

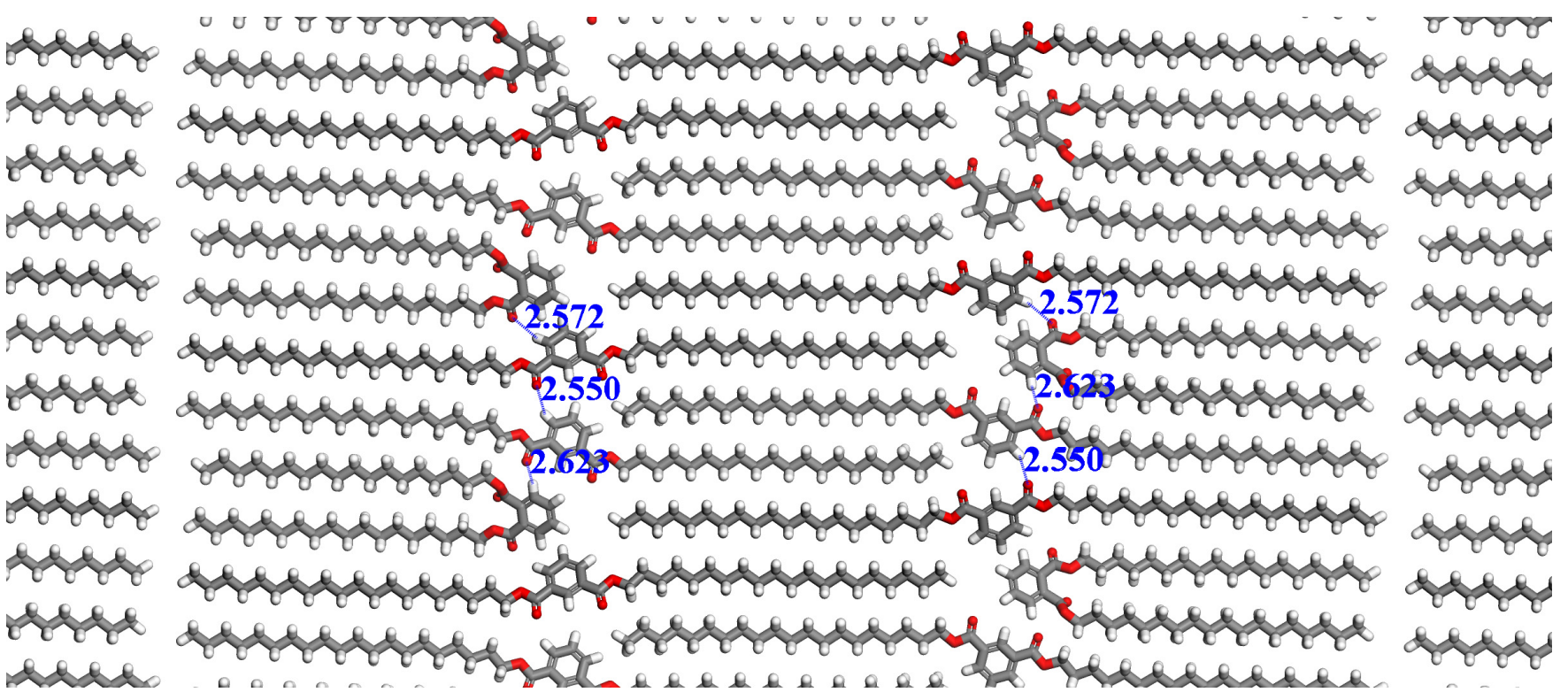

Figure S4. Computational model of the 18-ortho/20-meta cocrystal with the close C-H...O contact distances $(\AA)$ labeled. 
(8) Hypothetical model of 18-ortho/18-meta cocrystal

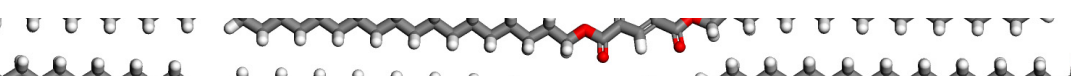

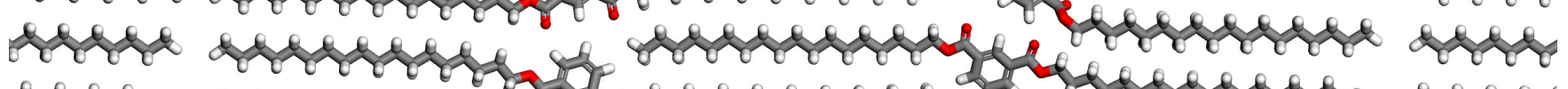

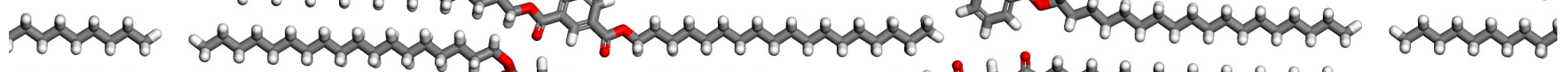

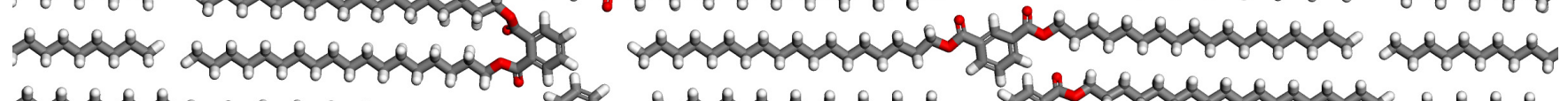

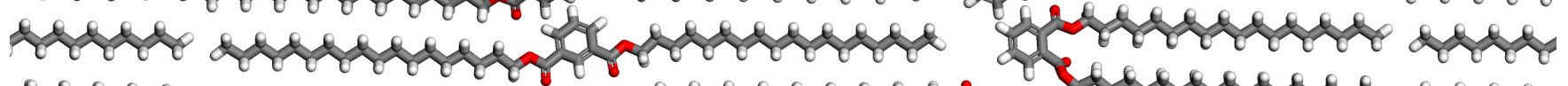

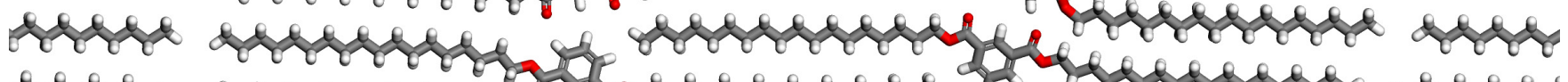

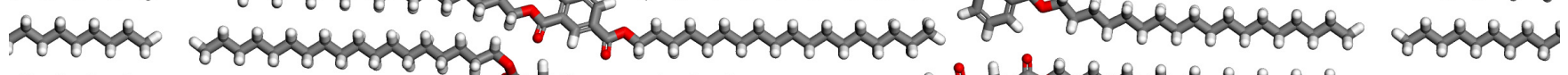

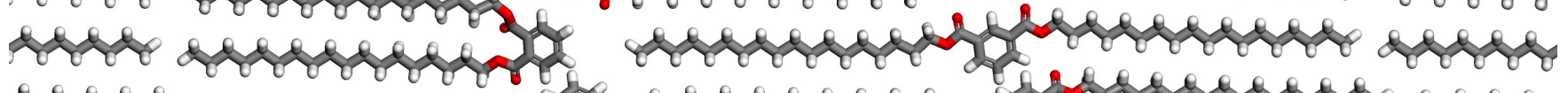

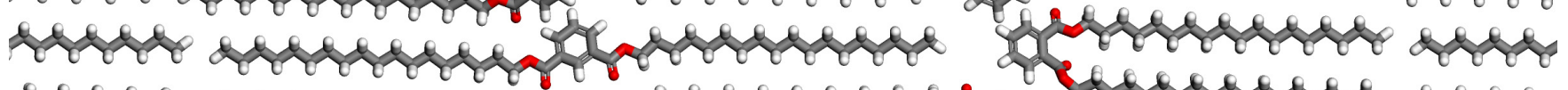

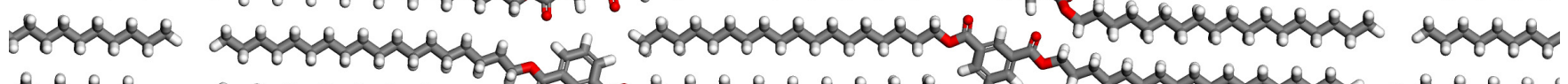

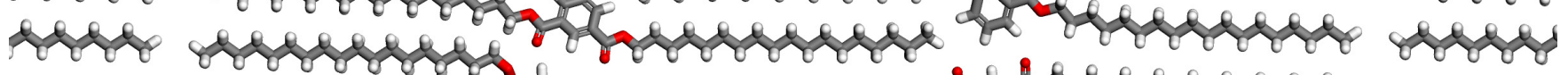

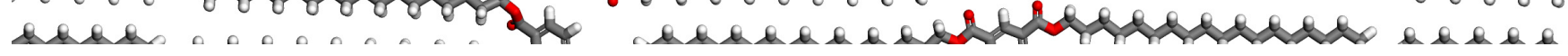

Figure S5. Computational model of the theoretical cocrystal of 18-ortho and 18-meta in a structure analogous to the observed 18-ortho/20-meta cocrystal. Note the highly uneven alignment of the methyl groups that makes this form unfavorable. 
The molecular surface area (Table S3) was determined from individual molecules taken from models minimized on a nonperiodic graphite slab. Atoms jutting out of the plane that could overlap other atoms were deleted in order to obtain the surface area that would contact the surface. The models were made in Materials Studio (Version 2.2, Copyright@ 2002 Accelrys) using CPK models with 0.85 scale. The resulting image, containing all molecules at the same scale, was analyzed using ScionImage software to determine the area of each molecule in its various conformations. From these values, the total molecular surface area was calculated. This value is a measure of the amount of surface area that the molecules take up in the unit cell. Packing coefficient is obtained by dividing the molecular surface area in one unit cell by the area of the cell. This gives a percentage value of the amount of space occupied within the cell. Note that this is necessary to determine which are the more densely packed structures, because mass and molar density are not comparable among packings involving molecules with different molecular weights.

Table S3. Calculation of molecular surface areas for packing coefficient.

\begin{tabular}{|c|c|c|c|c|c|c|c|c|}
\hline & \multirow{2}{*}{$\begin{array}{l}\text { total } \\
\text { number of } \\
\text { molecules } \\
\text { in unit cell }\end{array}$} & \multicolumn{2}{|c|}{ 18-ortho } & \multicolumn{2}{|c|}{ 18-meta } & \multicolumn{2}{|c|}{ 20-meta } & \multirow{2}{*}{$\begin{array}{c}\text { total } \\
\text { molecular } \\
\text { surface } \\
\text { area in } \\
\text { unit cell } \\
\left(\mathrm{nm}^{2}\right)\end{array}$} \\
\hline & & $\begin{array}{c}\text { number } \\
\text { in unit } \\
\text { cell }\end{array}$ & $\begin{array}{c}\text { area per } \\
\text { molecule } \\
\left(\mathrm{nm}^{2}\right)\end{array}$ & $\begin{array}{c}\text { number } \\
\text { in unit } \\
\text { cell }\end{array}$ & $\begin{array}{c}\text { area per } \\
\text { molecule } \\
\left(\mathrm{nm}^{2}\right)\end{array}$ & $\begin{array}{c}\text { number } \\
\text { in unit } \\
\text { cell }\end{array}$ & $\begin{array}{l}\text { area per } \\
\text { molecule } \\
\left(\mathrm{nm}^{2}\right)\end{array}$ & \\
\hline 18-ortho & 2 & 2 & 1.68 & - & - & - & - & 3.36 \\
\hline $\begin{array}{l}\text { 18-orthol } \\
20 \text {-meta }\end{array}$ & 6 & 2 & 1.67 & - & - & 4 & 2.00 & 11.34 \\
\hline 18-meta & 2 & - & - & 2 & 1.84 & - & - & 3.68 \\
\hline $\begin{array}{c}18- \\
\text { ortho/18- } \\
\text { meta }\end{array}$ & 8 & 4 & 1.83 & 4 & 1.72 & & & 14.2 \\
\hline 20-meta & 2 & - & - & - & - & 2 & 2.00 & 4 \\
\hline
\end{tabular}


Table S4. Packing coefficients and densities calculated using model and experimental data.

\begin{tabular}{|c|c|c|c|c|c|c|c|}
\hline \multirow{2}{*}{\multicolumn{2}{|c|}{$\begin{array}{c}\text { total } \\
\text { molecular } \\
\text { surface area } \\
\text { in unit cell } \\
\left(\mathrm{nm}^{2}\right)\end{array}$}} & \multicolumn{3}{|c|}{ experimental } & \multicolumn{3}{|c|}{ models } \\
\hline & & $\begin{array}{l}\text { unit cell } \\
\text { area } \\
\left(\mathrm{nm}^{2}\right)\end{array}$ & $\begin{array}{l}\text { packing } \\
\text { coefficient }\end{array}$ & $\begin{array}{c}\text { density } \\
\left(\mathrm{Da} \mathrm{nm}^{-2}\right)\end{array}$ & $\begin{array}{c}\text { unit } \\
\text { cell } \\
\text { area } \\
\left(\mathrm{nm}^{2}\right)\end{array}$ & $\begin{array}{c}\text { packing } \\
\text { coefficient }\end{array}$ & $\begin{array}{c}\text { density } \\
\left(\mathrm{Da} \mathrm{nm}^{-2}\right)\end{array}$ \\
\hline 18-ortho & 3.4 & 6.1 & 0.55 & 218 & 5.0 & 0.65 & 260 \\
\hline $\begin{array}{c}18- \\
\text { ortho/18- } \\
\text { meta }\end{array}$ & 14.2 & 18.4 & 0.77 & 292 & 21.3 & 0.67 & 252 \\
\hline 18-meta & 3.7 & 5.4 & 0.69 & 251 & 5.5 & 0.67 & 244 \\
\hline $\begin{array}{c}18- \\
\text { ortho/20- } \\
\text { meta }\end{array}$ & 11.3 & 18.6 & 0.61 & 229 & 16.8 & 0.67 & 253 \\
\hline 20-meta & 4.0 & 5.2 & 0.77 & 281 & 5.0 & 0.67 & 245 \\
\hline
\end{tabular}

